\title{
Islamic fundamentalism, nation- state and global citizenship: the case of Hizb ut-Tahrir
}

\author{
Asep Muhamad Iqbal and Zulkifli \\ Institut Agama Islam Negeri Palangka Raya, Kalimantan Tengah \\ E-mail:am.iqbal@iain-palangkaraya.ac.id; \\ Universitas Islam Negeri Syarif Hidayatullah Jakarta \\ E-mail:zulkifli@uinjkt.ac.id; zulharmi@gmail.com \\ DOI: 10.18326/ijims.v6i1.35-61
}

\begin{abstract}
Contrary to common understanding among observers, this essay argues that Islamic fundamentalism is not anti-globalization movement, but rather as parts, participants, and interpreters of globalization. Focusing on the case of Hizb ut-Tahrir, it shows that regardless of its utopian nature of the ideology it promotes, Islamic fundamentalism is a globalizing force that constitutes a return of old world religions to modern society, which is characterised by its rejection of the validity of nation-states and vision of a global citizenship through the establishment of Islamic Caliphate as a single global community of believers (ummah) with its universalistic rules and laws within contemporary Muslim world.
\end{abstract}

Berbeda dari pandangan yang sejauh ini banyak dikemukakan oleh para pengamat, tulisan ini berargumen bahwa fundamentalisme Islam bukan merupakan gerakan anti-globalisasi, melainkan justru sebagai bagian, partisipan dan penafsir fenomena globalisasi. Dengan memfokuskan analisisnya pada kasus 
Hizb ut-Tahrir, tulisan ini menunjukkan bahwa terlepas dari sifat utopian ideologi yang diusungnya, gerakan fundamentalisme Islam tidak diragukan lagi merupakan sebuah kekuatan globalisasi yang mewakili kembalinya agama besar dunia ke masyarakat modern, yang bercirikan penolakan atas validitas negarabangsa dan visi kewarganegaraan global melalui pembentukan komunitas global umat Islam dalam bentuk khilafah Islam dengan aturan dan hukum universalnya dalam dunia Islam kontemporer.

Keywords: Islamic fundamentalism; Nation-states; Global citizenship; Hizb ut-Tahrir

\section{Introduction}

Observers believe that fundamentalism is a reactionary movement to particular socio-economic and political circumstances, particularly Western global forces of economic, political and cultural changes. Since the world is shrinking, people become interconnected and interdependent so that traditions, religions and cultures are under threat of the globalizing forces. In response to this, fundamentalists turn to violence and terrorism to stop the erosion of their cultures and traditions. Furthermore, the rise of national and religious nationalism in a global world such as in the Middle East, former Yugoslavia, South Asia, and Japan, and the emergence of right-wing movements in Europe and the United States constitute as evidence that "globalization has not reached all quarters of the globe". ${ }^{2}$

Following these arguments, Islamic fundamentalism, for example, has been looked at as a threat and opposition to globalization particularly after 9/11. It is regarded as war between "MacWorld and Jihad", ${ }^{2}$ a reac-

${ }^{1}$ Mark Jurgensmeyer, “Thinking Globally about Religion', in Global E्F International Studies Program, Santa Barbara: University of California, 2002.

${ }^{2}$ Benjamin Barber, "Democracy and Terror in the Era of Jihad vs. McWorld', in K. Booth and T. Dunne, Worlds in Collision: Terror and the Future of Global Order, Basingstoke: Palgrave, 2002. 
tion to "coca-colonization" and American power, ${ }^{3}$ said as "a socio-political protest movement sugar-coated with religious pieties", 4 and considered as a "part of a larger phenomena of anti-globalization and tension between the have and have-not nations".

However, such assumptions are simplified attempts to understand the complex structure of fundamentalism. Moreover, they reinforce "the neglect of a fundamentalist system of ideas as a substantive vision of the world". ${ }^{6}$ It is more appropriate to see the phenomena of new nationalism and fundamentalism as "products of one or more of several globalizing forces". They are "further examples" of globalization impacts and "responses to the insufficiencies of the secular construct of nationalism"?

Like new social movements, Islamic fundamentalism "is a relativising force within the processes of globalization, not aiming at negating global reality but at shaping it". ${ }^{8}$ It is "a way of asserting a particular (group) identity, which in turn is a prime method of competing for power and influence in the global system". 9 In achieving this, Islamic fundamentalism operates in a global level transcending nation-states, but not necessarily in opposition to nations-states.

In this essay, we support a proposition that Islamic fundamentalism is better understood as a globalization in itself or at least as a part of globalizing forces. We argue that Islamic fundamentalism is not anti-globaliza-

${ }^{3}$ Martha Crenshaw, "Why America? The Globalization of Civil War', Current History, December (2001), 425-432.

${ }^{4}$ Martin E. Marty and R. Scott Appleby, Fundamentalism Comprehended, Chicago: Chicago University Press, 1995.

${ }^{5}$ Audrey Kurth Cronin, "Behind the Curve: Globalization and International Terrorism”, International Security, Vol. 27, No.3, Winter (2002-2003), 30-58.

${ }^{6}$ Roxanne L. Euben, Enemy in the Mirror: Islamic Fundamentalism and the Limits of Modernity, Princeton: Princeton University Press,1999.

7Jurgensmeyer, "Thinking Globally".

${ }^{8}$ Lina Khatib, "Communicating Islamic Fundamentalism as a Global Citizenship", Journal of Communication Inquiry, 27, No. 4 ( 2003), 391.

${ }^{9}$ Peter Beyer, Religion and Globalization, London: Sage publications, 1994, 4. 
tion movement, but rather as parts, participants, and interpreters of globalization. In doing so, we will focus on Hizb ut-Tahrir (Liberation Party), a global Islamic fundamentalist movement, its transnational presence, and its vision of global Muslim community. Its importance lies in the fact that, like globalization, Hizb ut-Tahrir challenges the existence of Westphalian nation-states ${ }^{10}$ and constitutes a potential force for establishing a global citizenship.

\section{Islamic fundamentalism defined}

There is a disagreement among scholars in regard to the definition of Islamic fundamentalism. Some even disagree with the term "fundamentalism" as historically it is closely associated with Christian fundamentalist movement, particularly Protestantism, in the early twentieth century in the United States of America. The term has been defined from various angles. Islamic fundamentalism refers to "the growth of Islam as a religious force and a political ideology and ... to desire to reinstate the Islamic legal law". ${ }^{11}$ It is defined as "the emotional, spiritual and political response of Muslims to an acute and continuing social, economical and political crisis that has gripped the Middle East". ${ }^{12}$ It is also defined as a challenge to the United States's position as a global power ${ }^{13}$ and an oppo-

\footnotetext{
${ }^{10}$ Westphalian nation-states refer to a state system in which each nation-state has sovereignty over its territory and domestic affairs, has right to exclude all external power and interference, and to be equal before international law. The name was derived from the Treaty of Westphalia, signed in 1648, which ended the Thirty Year's War of $17^{\text {th }}$ century Europe. See Gregory A. Raymond, "Westphalia", in Encyclopedia of International Relations and Global Politics, ed. M. Griffiths, London: Routledge, 2005, 856.

${ }^{11}$ Bryan White, Richard Little and Michael Smith (eds.), Issues in World Politics,London: McMillan Press, 1997 as cited in Khatib, "Communicating Islamic Fundamentalism”, 392.

${ }^{12}$ Anourshiravan Ehteshami, "Islamic Fundamentalism and Political Islam", in White, et al., Issues in World Politics, 179-199 as cited in Khatib," Communicating Islamic Fundamentalism”, 392.

${ }^{13}$ Amin Saikal, "Islam and the West”, in Greg Fry \& Jacinta O'Hagan (Eds.), Contending Images of World Politics, London: McMillab Press, 2000, 164-177.
} 
sition to the Western ideologies such as secularism. ${ }^{14}$ It is also inaccurately seen as terrorism. ${ }^{15}$ Lastly, Islamic fundamentalism is defined loosely as "a diverse set of competing political opinions held within the Muslim community". ${ }^{16}$

Regardless of this disagreement, there is a common set of characteristics shared by various Islamic fundamentalisms that can be used as a base to define Islamic fundamentalism. A movement can be defined as Islamic fundamentalism if it meets the following characteristics. First, it views itself not only as religious movement, but also political one. Second, it believes in the authenticity and coherence of Islam as an alternative to Western hegemony. Finally, it views jihad as a necessary to preserve and expand Muslim community, though the interpretation and application of jihad can be different among Islamic fundamentalist groups. ${ }^{17}$

\section{Islamic fundamentalism as source, component and interpreter of globalization}

Following Lechner that "religion is, and has been, involved in globalization in various ways-as source, component and interpreter of globalization" ${ }^{18}$ we think that Islamic fundamentalism has been a source of globalization in the sense that it helps establish global and inter-state relations, encourages and approves the spread of such relations, and commu-

\footnotetext{
${ }^{14}$ Hamid Mowlana, "The Renewal of the Global Media Debate:Implications for the Relationship between West and the Islamic World", in Kai Hafez (ed.), Islam and the West in the Mass Media ,Cresskil, NJ: Hampton Press, 2000, 105-118.

${ }^{15}$ White, et al. Issues in World, as cited in Khatib, "Communicating Islamic Fundamentalism”, 392.

${ }^{16}$ Khatib, "Communicating Islamic Fundamentalism", 393.

${ }^{17}$ Khatib, "Communicating Islamic Fundamentalism", 393.

${ }^{18}$ Frank J. Lechner, "Defining Religion: A Pluralistic Approach for the Global Age", paper for the Society for the Scientific Study of Rreligion meeting, Houston, October 2000.
} 
nicates the awareness of global world. It is true that measured against the scope of global business, finance, media and so on, the significance of fundamentalism is relatively low. But, it cannot be ignored that for the global proponents of Islamic fundamentalism, puritan way of religious life and understanding has served as model and stimulus for building transnational practices and institutions. ${ }^{19}$

Islamic fundamentalism also has been a component of globalization. Like other global forces, Islamic fundamentalism gets actively involved in transnational activities. The protagonists of Islamic fundamentalism spread their thoughts transcending national borders through global communication technology, transnational migration, as well as personal contacts. The internet technology particularly plays a crucial role in making Islam fundamentalist groups a part of the globalizing forces. Though they might be conservative in understanding their religious doctrine, fundamentalists are modern in that they have utilised cyberspace as an inevitable medium for their interests and needs. ${ }^{20}$ Islamic fundamentalism now has become a global force in that it spreads across the national borders articulating Held and McGrew's three dimensions of globalization: material, spatio-temporal, and cognitive. ${ }^{21}$ It is actively engaged in the globalization of material exchanging flow of trade, happenings and repercussions between its members and sympathizers across the nationstates. It takes a part and carries out interregional and global meetings across time and space. It also involves in the globalization of cognitive disseminating its ideas and visions beyond the nation-state. ${ }^{22}$

\footnotetext{
${ }^{19}$ Lechner, "Defining Religion".

${ }^{20}$ Lechner, "Defining Religion".

${ }^{21}$ David Held \& Anthony McGrew, "The Great Globalization Debate: An Introduction", in David Held and Anthony McGrew (eds.), The Global Transformation Reader: An Introduction to the Globalization Debate, London: Polity Press, 2000, 1-45.

${ }^{22}$ Khatib, "Communicating Islamic Fundamentalism", 393
} 
Furthermore, globalization carries a universal problem to the world society, namely the problem of globality. ${ }^{23}$ In response to this, Islamic fundamentalism is concerned with how to make global life meaningful. In doing so, Islamic fundamentalist groups identify themselves and position themselves in relation to global processes. ${ }^{24}$ They interpret the problem of globality in the interest of the ideological structure and vision of their movement. To a large extent, their interpretation of globalization ranges from critical stance to rejection of the current world. To some degree, these responses appear as reactionary to global forces that challenge the basic structure of their faith. But, a closer look will reveal that such responses are particular ways of how fundamentalist perceive themselves as a part of global forces and so that better situated within the context of their way of interpreting globalization.

\section{Islamic fundamentalism and nation-state}

Globalization undoubtedly challenges the modern idea of nation-state and nationalism. This is particulalarly seen in its global reach of transnational business and commerce, labor supply, currency, and finance. Globalization embraces the planetary expansion of communication technology, culture, economy, politics and environmental issues. ${ }^{25}$

Today, the nation-state is facing not only the challenge of "secular" globalization, but also opposition from "religious" globalization such as the one promoted by Islamic fundamentalism. The Islamic fundamentalism phenomenon attempts to provide alternatives ideas and visions to the current global situations. For example, it offers a vision for constructing a single global culture under the banner of the global ummah (com-

\footnotetext{
${ }^{23}$ Roland Robertson, Globalization: Social Theory and Global Culture, London: Sage, 1992; and Martin Albrow, The Global Age,Stanford: Stanford University Press, 1996.

${ }^{24}$ Lechner, "Defining Religion".

${ }^{25}$ Jurgensmeyer, "Thinking Globally".
} 
munity of believers). This vision certainly challenges the Westphalian form of nation-states as it envisions a new global citizenship which is based not ethnicity or nationality, but on faith. Sayyid Qutb (d. 1966), an ideologue of the Ikhwan al-Muslimin (the Muslim Brotherhood) fundamentalist movement, said that "a Muslim's nationality is his religion". ${ }^{26}$ The fundamentalist vision of a global Islamic state that "divorced from territorial states" has led Appadurai to view the Islamic fundamentalist identity as "postnational". 27

The spread of Islamic fundamentalism in Arab countries can be seen as a response to the failure of nation-sate to create national and regional identity, in addition to its failure to provide economic progress and political stability. This is exemplified by the idea of Pan-Arabism as a reaction to colonialism advocated by Egyptian president, Gamal Abdel Nasser, which failed to create Arab unity. This in turn brought about the emergence of Islamic fundamentalism advocated by the Ikhwan al-Muslimin led by, among others, Sayyid Qutb. It has risen as a substitute to the nation-state that failed to establish Arab identity. ${ }^{28}$

Nevertheless, Islamic fundamentalism has not always opposed against the nation-state. Rather, it might help to reinforce the existence of nation as seen in its uses by Islamists to expel British from Egypt in 1920s and Soviet Union from Afghanistan at the end 1980s. Islamic fundamentalism has been actively engaged in activities to expel Israel from South Lebanon. ${ }^{29}$

\footnotetext{
${ }^{26}$ Khatib, "Communicating Islamic Fundamentalism", 393.

${ }^{27}$ Arjun Appadurai, Modernity at Large: Cultural Dimensions of Globalization Minneapolis: University of Minnesota Press, 1996 as cited in Khatib, "Communicating Islamic Fundamentalis", 393.

${ }^{28}$ Khatib, "Communicating Islamic Fundamentalism", 394.

${ }^{29}$ Khatib, "Communicating Islamic Fundamentalism", 393.
} 


\section{The case of Hizb ut-Tahrir}

Hizb ut-Tahrir (Liberation Party) was founded in 1953 by Taqi al-Din alNabhani (1909-1977), a well-known al-Azhar-educated Islamic scholar and judge in the appeal court in East Jerusalem. During his study at al-Azhar, al-Nabhani had interactions with members of the Muslim Brotherhood, but it is not known whether he ever became its member. When he died in 1977, Hizb ut-Tahrir was then led by Abdul Qadeem Zaloom, a founding member of Palestinian origin. Another Palestinian, Ata Abu al-Rushta, a former party spokesman in Jordan, replaced Zaloom when he died in 2003.30

Hizb ut-Tahrir describes itself as a political party, not as a religious organization, whose ideology is Islam. Its stated goal is to implement the Islamic way of life and to revive the Muslim ummah through the establishment of a single Islamic state. ${ }^{31}$ But, it is not registered anywhere as it operates in the Muslim world and encourages Muslims not to participate in the existing political parties because they are considered to be 'fake Islamic parties'. Al-Nabhani says:

Hizb ut-Tahrir is a political party, whose ideology is Islam and its goal is to resume the Islamic way of life by establishing the Islamic state which implements Islam and carries its da'wah to the world. The Hizb has developed a party culture, which includes Islamic rules about life's affairs. The Hizb calls for Islam as an intellectual leadership from which emanates systems that address all problems faced by human beings, whether political, economic, cultural, social and others. It is a political $\mathrm{Hizb}$ whose members include both men and women. It calls all people to Islam and to adopt its concepts and systems and views them, no

${ }^{30}$ Emmanuel Karagiannis \& Clark McCauley, "Hizb ut-Tahrir al-Islami: Evaluating the Threat Posed by a Radical Islamic Group that Remains Nonviolent", Terrorism and Political Violence, 18 (2006), 315-334.

${ }^{31}$ Reza Pankhurst, The Inevitable Caliphate: A History of the Struggle for Global Islamic Union, 1924 to the Present, New York: Oxford University Press, 2013, 95. 
matter what their nationalities and schools of thought, from the Islamic outlook. It relies on the interaction with the Ummah to achieve its goal. It stands against colonialism in all its forms and aims to liberate the Ummah from the colonialist intellectual leadership and to remove its cultural, political, military, economic influence from the Islamic lands. It also aims to change the erroneous and distorted concepts spread by collonialism that restricts Islam to personal worship and morals. ${ }^{32}$

The movement develops its ideological platform based on al-Nabhani's writings. Its political doctrine is founded on two principles: first, the need for shariah, Islamic law, to establish a just society, and second, the need for Islamic state as the only political entity that is able to create a just society. Like other Islamic fundamentalist movements, Hizb ut-Tahrir does not recognize the separation between $\operatorname{din}$ (faith) and dawlah (state). ${ }^{33}$

Hizb ut-Tahrir disseminates its political ideology through a network of underground cells that operates in several levels. At the lowest level, new members are recruited and then organized in a halqa (study circle) consisting five people. Under supervision of a mushrif (supervisor; the head of a study circle), the members study the movement's doctrines. At the district level, a local committee is established and responsible for organizing group affairs. Within this system, internal discipline and obedience to the leader are very important to keep the solidity of the movement and to prevent the infiltration by security agents. ${ }^{34}$ Hizb ut-Tahrir divides the world into wilayahs. A wilayah can constitute a nation-state or a particular region of nation-states. Within a wilayah, there is a mu'tamad (the provincial representative) that is appointed by lajnah al-qiyadah (the central committee) of the international party. ${ }^{35}$

\footnotetext{
${ }^{32}$ Taqiuddin al-Nabhani, n.d. Concepts of Hizb ut-Tahrir (Mafahim Hizb ut-Tahrir). London: Khilafah Publications, 76.

${ }^{33}$ Karagiannis \& McCauley, "Hizb ut-Tahrir", 317.

${ }^{34}$ Karagiannis \& McCauley, "Hizb ut-Tahrir", 317.

${ }^{35}$ Karagiannis \& McCauley, "Hizb ut-Tahrir", 317.
} 


\section{Hizb ut-Tahrir as a part and an interpreter of globalization}

\section{Hizb ut-Tahrir's global network}

Hizb ut-Tahrir is an active participant in the globalization processes. This can be seen in its global network that far transcends its country of origin in the Middle East. As a global Islamic political party, Hizb utTahrir operates across national borders. Its members are active throughout the Middle East, Central Asia, South East Asia, Africa, the Indian subcontinent, Australia, Europe and America. During the last five years, Hizb ut-Tahrir has been present in approximately 45 countries. Its several branches have become large enough to transform from underground operation to public activities stage, such as those in Australia, Belgium, Denmark, Malaysia, Palestine, Pakistan, Turkey and Bangladesh. ${ }^{36}$ It rejects an assumption speculated by observers such as Zeyno Baran that its UK branch is the most important and Britain is the base for the movement. For Hizb ut-Tahrir, this is mistaken as the main arena of its political work is not a particular country, but rather the Muslim world. The leadership of the current global leader, Ata Abu Rushta, encompasses the Muslim world. ${ }^{37}$

\section{Middle East}

Though it is not easy to estimate the accurate number of its membership, the presence of Hizb ut-Tahrir is felt worldwide. In the Middle East, the movement began its early activities in Jordan, where many of its members were arrested after the government accused them of involving in the military coup, a charge later proven untrue in a subsequent court case. Though it does not gain serious influence among society, Hizb ut-

\footnotetext{
${ }^{36}$ Medeleine Gruen, "Hizb-ut-Tahrir's Activities in the United States', Terrorism Monitor, Vol. V, Issue 16 (2007), 7-9.

${ }^{37}$ Hizb ut Tahrir Britain, "Media Pack".
} 
Tahrir continues to work in Jordan. ${ }^{38}$ It also operates in Syria, where its members were arrested in 1999 by security forces. In Iraq, Hizb ut-Tahrir experienced a serious pressure from the Saddam Husein's regime and its members were executed in 1990 after calling Saddam to establish an Islamic state. But, it gained a good momentum after the fall of Saddam regime and opened an Iraqi branch in 2003. Hizb ut-Tahrir has operated in Africa such as Egypt, Tunisia, Libya, Algeria and Sudan, although its members faced imprisonment from governments. Its presence is also felt in Turkey though the state restricted its members' activities. ${ }^{39}$

\section{Europe}

Hizb ut-Tahrir is growing rapidly in Western Europe, particularly among the second and third generations of Muslim immigrants. Its attraction lies in its message of a just Islamic order as an alternative for democracy and capitalism which are perceived critically by these new Muslim generations. In addition, ethnic and religious discrimination faced by Muslims minority helps increase the party's popularity in Western Europe. All this has provided Hizb ut-Tahrir with a strong organizational and financial base for developing its activities in the continent. ${ }^{40}$

Hizb ut-Tahrir has gained support from Muslim immigrants in Sweden, Germany and Denmark. But, the party was banned in Germany and Denmark in 2003 as its members were accused of spreading antiSemitic and Israeli propaganda and having a link with terrorist groups. But, the German authorities did not provide evidence for Hizb ut-Tahrir's

\footnotetext{
${ }^{38}$ International Crisis Group (ICG), "Radical Islam in Central Asia: Responding to Hizb ut-Tahrir”, Asia Report, No. 58, 2003.

${ }^{39}$ ICG, "Radical Islam".

${ }^{40}$ Robert A. Saunders, "The Ummah as Nation: A Reappraisal in the Wake of the "Cartoon Affairs", Nations and Nationalism, 14, 2 (2008), 303-321; and ICG, "Radical Islam”, 2003.
} 
link with terrorist groups and the allegation of its anti-Semitic propaganda resulted from miscomprehension of the quotes which were taken out of context. ${ }^{41}$

In UK, Hizb ut-Tahrir has grown quickly after the Gulf War from a relatively unknown organization to perhaps most popular Islamic movement in Britain. It operates actively, particularly among university campuses, in London and cities with a great number of Muslim populations such as Birmingham, Sheffield and Bradford. It gained a controversial Media reputation when its leader, Omar Bakri Muhammad, expressed his denial of holocaust and his inflammatory rhetoric increased tension between Hizb ut-Tahrir, Hindi and Jewish students. After the leadership of Omar Bakri, who was dismissed from his office by the party's international leadership in 1996, British Hizb ut-Tahrir presents itself as media friendly, moderate, and much careful to avoid any misinterpretation of their messages. ${ }^{42}$

\section{America}

Hizb ut-Tahrir development was considered slow in its first thirteen years of presence in the United State. But, it has continued to grow like other branches and now is showing signs of vitality. In its early development, Hizb ut-Tahrir had a presence in Orange County and Queens, New York. The recent developments indicate that its membership has flourished beyond New York, Orange County, Chicago and Milwaukee, with Midwest as the base for its most influential members. Due to its success in using new media and access to international student, Hizb ut-Tahrir America seems to play an important role in the global Hizb ut-Tahrir network and it is predicted to continue to grow significantly in the next decade. ${ }^{43}$

${ }^{41}$ ICG, "Radical Islam".

${ }^{42}$ ICG, "Radical Islam".

${ }^{43}$ Gruen, "Hizb-ut-Tahrir's Activities". 


\section{Asia}

Hizb ut-Tahrir has attempted to spread its network to Asia. Its global target areas include countries in Central Asia, South Asian and Southeast Asia. Since the early 1990s, the movement has been active in Central Asia countries, such as Kazakhstan, Uzbekistan, Kyrgyzstan, and Tajikistan. The authorities of these countries have responded repressively to Hizb ut-Tahrir members, but they have been unable to eradicate their activities. In fact, repressive measures have shown the opposite effect: Hizb ut-Tahrir is gaining popularity among people of Central Asia. It is not easy to know membership as the movement operates clandestinely. But, it is estimated that the party membership ranges from 30,000 to $100,000.44$

In Southeast Asia, Indonesia has become a fertile ground for growing Hizb ut-Tahrir. Its presence can be traced back to the early 1980s when it was brought in to Indonesia by Abdurrahman al-Baghdadi, an Australian of Jordanian-Lebanese origin. It operated underground at university campuses for the first fifteen years of its presence in Indonesia. But, since the fall of Suharto regime in 1998, it has enjoyed success in that it is able to operate publicly and university campuses remain its main base. Claiming tens of thousands of members, the party mobilized thousands of demonstrators to support the implementation of Islamic law in some cities in 2002 and to oppose the US invasion of Iraq in 2003. The members of Hizb ut-Tahrir freely hold rallies, public meetings and other activities without the state control, restrictions and imprisonment. ${ }^{45}$ In 2007, it successfully held the international khilafah (caliphate) conference in Jakarta's Gelora Bung Karno stadium with, as it claimed, 100.000 attendees from various countries. ${ }^{46}$ It is the world's largest in a series of conference

\footnotetext{
${ }^{44}$ Karagiannis \& McCauley,"Hizb ut-Tahrir", 316.

${ }^{45}$ ICG, "Radical Islam", 2003.

${ }^{46}$ See the website of Hizb ut- Tahrir Indonesia, www.hizbuttahrir.or.id
} 
organised by the Liberation Party as desire to create a single Islamic Caliphate. ${ }^{47}$

Though it has enjoyed less success compared with its presence in Indonesia, Hizb ut-Tahrir is growing in Pakistan. Its members propagate the movement ideology mostly in urban areas among the educated urban middle class ignoring rural areas which are little use for their political objectives. Among its target are opinion makers such as journalists, trade unionists, teachers and lawyers. To have public exposure, the movement holds rallies and demonstrations in support of Islamic state and implementation of sharia (Islamic law). It has used peaceful means to disseminate its ideology such as pamphlets, conferences, seminars, dawrah (religious study circles) and halaqah (religious trainings and workshops). ${ }^{48}$

\section{Hizb ut-Tahrir's global media}

Hizb ut-Tahrir's ideology is disseminated and distributed more effectively through various means of global communication. It was 'print capitalism' in the nineteenth century that played a key role in the development of the nation as imagined community. ${ }^{49}$ In the twenty first century, it is global media that has contributed to the rapid distribution of post-national citizenship. Similarly, global new media have played an important role in the development of the idea of global Muslim community as promoted by Hizb ut-Tahrir. Global communication has created a 'global village' blurring what is local and what is global, what is near and what is far, and private and public. The party considers the internet technology as an important medium for organizing its activities, recruiting new members and disseminating its influences and ideology. Proponents of Islamic

\footnotetext{
${ }^{47}$ Pankhurst, The Inevitable Caliphate..., 1.

${ }^{48}$ ICG, "Radical Islam", 2003.

${ }^{49}$ Benedict Anderson, Imagined Communities: Reflections on the Origin and Spread of Nationalism (revised edition), London: Verso, 2006.
} 
caliphate adopt cyberspace and adapt it to the maximum benefit for their needs and interests.

The proponents of Hizb ut-Tahrir are using global communication networks to exchange ideas, increase political strength and promote unity as the members of global ummah. Cyberspace is the most profound means and place in maintaining links among members as well as developing networks and propagation to non-members. The de-territorialized structure of the internet "has important ramifications for reifying the transnational ummah". ${ }^{50}$ The internet has enabled the members of Hizb ut-Tahrir around the world to create an "imagined community" of global Islamic community. It has erased the geographical boundaries so that enables them to extend their influence over diverse world population, exchange information, and maintain solidarity among themselves in different countries. It is true that "the internet stands in for the idea of ummah...and makes this ideal community concrete because one can interact with it" ${ }^{51}$ and "access to (and perhaps ownership of) the Internet has become a significant element of propagation and identity for Muslim individuals and organisations" ${ }^{52}$ The importance of cyberspace for Islamic fundamentalist movements such as Hizb ut-Tahrir has led observers to conclude that

Cyber Islamic Environments have the potential to transform aspects of religious understanding and expression, and the power to enable elements within the population to discuss aspects of religious interpretation and authority with each other, and to consult with authorities both from traditional and non-traditional centres, in some cases subverting what were conventional channels for opinions on religious issues. $^{53}$

${ }^{50}$ Saunders, "The Ummah as Nation"..., 312.

${ }^{51}$ Sageman as quoted in Saunders 2008.

${ }^{52}$ Gary Bunt, Islam in the Digital Age: E-Jihad, Online Fatwas and Cyber Islamic Environments, London: Pluto Press, 2003, 4.

${ }^{53}$ Bunt, Islam in the Digital Age..., 201-202. 
As a consequence, Hizb ut-Tahrir has become one of dominant forces in transnational politics, which emerges from the Muslim world's experience with globalization. In sum, "the rethinking of political community is largely a result of Muslims living in translocal spaces which are themselves the product of wider migratory and globalising processes" ${ }^{54}$ This Muslim group has been engaged in the process of what Mandaville calls "reimagining the Umma" 55 through the extensive use of media and information technologies that contribute to the development of a wider Muslim public sphere.

\section{Khilafah: rejection of nation-states and vision of an imagined global citizenship}

Hizb ut-Tahrir calls for the unification of all Muslim countries into a single global state of al-Khilafah al-Islamiyyah (the Islamic Caliphate). It rejects nationalism of all types and the existence of some countries that claim themselves to be the Islamic states such as Iran and Saudi Arabia because, in Hizb ut-Tahrir's claim, they do not meet the necessary criteria of an Islamic state. However, Hizb ut-Tahrir "takes the Arab lands that are a part of the Islamic lands as a starting point... considers the establishment of an Islamic state in the Arab countries as a nucleus for the Islamic state as a natural step". ${ }^{56}$

As a global political organization, Hizb ut-Tahrir aims to re-establish the Islamic Caliphate as a global independent state. The Islamic caliphate is set up upon mass popular support through non-violent means and strategy. It encompasses the Muslim world and then disseminates peacefully to other worlds. It is built upon an elected and accountable global

\footnotetext{
${ }^{54}$ Peter Mandaville, Transnational Muslims Politics:Reimagining the Umma, London and New York: Routledge, 2001, 191.

${ }^{55}$ Mandaville, Transnational Muslims Politics.

${ }^{56}$ Al-Nabhani, Concepts of Hizb ut-Tahrir..., 73.
} 
ruler, an independent judiciary, political parties, the rule of law and equal rights for minority groups. Citizens of the caliphate have right to get involved in politics as the khalifah (caliph)'s role is to serve people and govern with justice. ${ }^{57}$

Hizb ut-Tahrir believes that the return to the Qur'an and Sunnah (the practices and sayings of the Prophet Muhammad) is very essential in realising the global Islamic state. Claiming to follow the methods the Prophet Muhammad implemented in his mission in Mecca and Medina in the seventh century, Hizb ut-Tahrir outlines a three-stage program of action. This consists of the recruitment of the elite party members, Islamization of the society and takeover of the state and spreading Islam to the world.

First, Hizb ut-Tahrir "builds its cadres, while engaging society in an ideological struggle on intellectual and political fronts. On the intellectual front, it exposes society's man-mad laws and non-Islamic way of life aiming to reshape people's ideas and emotions. On the political front, the struggle is manifest in the fight against imperialist influences and the exposure of conspiracies hatched against the ummah by its rulers". ${ }^{58}$ This stage involves the recruitment of individuals and educating them with the thought and methods of the movement. These individuals will constitute the elite party members that are believed to have capability to carry and disseminate the party's ideology. ${ }^{59}$

Second, the party is engaged in the collective interaction with society by launching its mission in earnest. This aims "to create a broad awareness of its ideology and a commitment to work for its implementation" ${ }^{60}$

\footnotetext{
${ }^{57}$ Hizb ut-Tahrir Britain, Media Pack.

${ }^{58}$ Suha Taji-Farouki, "Islamists and the Threat of Jihad: Hizb al-Tahrir and al-Muhajiroun on Israel and the Jews', Middle Eastern Studies, Vol. 36, No. 4 (2000), 23.

${ }^{59}$ Karagiannis \& McCauley, "Hizb ut-Tahrir"..., 318.

${ }^{60}$ Taji-Farouki, "Islamists and the Threat of Jihad:..., 23.
} 
This stage is the islamization of society by interacting with the ummah (the community of the believers). This aims to encourage people to embrace and internalize Islam in individual, community and state levels. ${ }^{61}$

The last stage is "establishing an Islamic state, implementing Islam generally and comprehensively, and carrying its message to the world" ${ }^{62}$ At this stage, Hizb ut-Tahrir "will consolidate its progress by soliciting the support of powerful groups in society that had pledged to assist it, leading into the final stage of implementing Islam via the erection of the caliphate". ${ }^{63}$

Details of the Islamic Caliphate are little elaborated in the literature published by Hizb ut-Tahrir. It is little said about actual power mechanism. But, it can be said that it is a mixture of elements of Caliphate, some are anachronistic, in the first centuries of Islam and aspects of the modern state. The elements of the global state envisioned by Hizb utTahrir include a Caliph as the ruler, who is elected by the Majlis al-Ummah (the People Assembly). The members of the assembly are elected by people. An amir (the leader) is appointed by the caliph and responsible for military affairs and external relations. Political parties are allowed in a condition they are based on Islamic ideology and support the Caliph and implementation of shariah. ${ }^{64}$

In economics, the Caliphate's policy is a return to gold and silver standard with dirham and dinar as its currencies, as practiced in the first centuries of Islam, and the replacement of capitalism with Islamic system of economy. Hizb ut-Tahrir believes that "the only thing that will save the world from the corruption of this Capitalist economic system, the public company system, the usurious banking system and the inconvertible pa-

\footnotetext{
${ }^{61}$ Karagiannis \& McCauley, “Hizb ut-Tahrir”..., 318.

${ }^{62}$ Karagiannis \& McCauley, "Hizb ut-Tahrir"..., 318.

${ }^{63}$ Taji-Farouki, "Islamists and the Threat of Jihad..., 23.

${ }^{64} \mathrm{ICG}$, "Radical Islam".
} 
per money is the abolishment of this corrupt Capitalist system... To save the world from this malaise, the usurious banking system and the inconvertible paper money standards must be abolished and a return the gold and silver standards initiated". ${ }^{65}$

Hizb ut-Tharir believes that the new caliphate will be established not through gradual change by involving in the politics of current states, but rather through peaceful evolutionary power takeover with full mass support. This view distinguishes Hizb ut-Tahrir from other fundamentalist Muslim groups such as Ikhwan al-Muslimin (the Muslim Brotherhood) who have sought to apply Islamic ideas gradually within existing constitutional frameworks through gradual reform in politics and education. Hizb ut-Tahrir rejects this gradual approach completely arguing that only a radical transformation of society through peaceful power seizure with mass support will create change in Muslim community. ${ }^{66}$

Therefore, Hizb ut-Tahrir does not recognize the existing attempts by Islamic parties and fundamentalist Islamic groups to establish an Islamic state. It claims that Sudan, Iran, Saudi Arabia and other Muslim countries that proclaim Islam as their constitution are not Islamic states because they do not meet the required criteria. ${ }^{67}$ It believes that Islamic state is founded on two principles. First, it is must based on Islamic law (shariah) that regulates all aspects of individual and public lives of socity politics, economics, ethics and sciences. Hizb ut-Tahrir views that, "for a land to be considered an Islamic state, every single article of the country's constitution, every rule and law must emanate from the Islamic shariah". Second, it is created on the idea of authentic Islamic state which recognizes no separation between faith and the state, between religion and

\footnotetext{
${ }^{65} \mathrm{ICG}$, "Radical Islam".

${ }^{66} \mathrm{ICG}$, "Radical Islam".

${ }^{67}$ Karagiannis and McCauley, "Hizb ut-Tahrir"..., 317.
} 
politics like the Westphalian model of the nation-state. Islam is regarded as a complete way of life that provides rules for individuals, society, and the state. ${ }^{68}$

This straightforward and ambitious aim is a utopian interpretation of the caliphate that ruled the Muslim world, from the era of the early caliphate, known as al-khulafau al-rashidin (the rightly guided caliphates) after the death of the Prophet Muhammad until the Ottoman caliphate that was disbanded by Turkish leader Kemal Ataturk in 1924. Hizb utTahrir's stated aim of recreating the Islamic Caliphate might be flawed as it is based on ahistorical understanding of the Caliphate. It believes that the Islamic caliphate was a unitary Islamic empire in which all Muslim countries were under a single command and leadership of the caliph. In fact, the Caliphate as single unitary political entity with full obedience and support of all Muslim people in the world has never existed at least since $850 \mathrm{AD}$. It might be true that authority of four caliphs after the death of the Prophet covered all Muslims societies when Islam had not expanded internationally. But, the following caliphates, such as Umayyad and Abbasid and Turkish Ottoman, witnessed division among Muslim communities and symbolic posts of the Caliphs used for foreign policy purposes. The vision of re-establishment of Islamic state modelled on the one believed to have existed in the Muslim history can be said as an attempt to apply a system of governance which was used in less complex society to much more complex contemporary society. As Taji-Farouki says, "an-Nabhani attempted to resurrect models reflecting the socio-economic life of societies much less complex than today's, making little allowance for the needs and circumstances of the contemporary age" ${ }^{69}$

\footnotetext{
${ }^{68} \mathrm{Hizb}$ ut-Tahrir Britain, "Media Pack"; Karagiannis and McCauley, "Hizb ut-Tahrir"...,317. ${ }^{69} \mathrm{ICG}$, "Radical Islam".
} 
It appeared that al-Nabhani himself realized this by admitting that to establish the Islamic state is not an easy task because there are many obstacles that must be removed and dismantled, including colonial cultural, economic, and political influence on Muslims and Muslim countires. He says:

The only way to establish the Islamic state is to carry the Islamic Message and to work towards the resumption of the Islamic way of life, which necessitates taking the Islamic countries all together as one unit because the Muslims are but one Ummah, which represents a human group bound by one 'Aqeedah from which emanates her system. ${ }^{70}$

In addition, members of Hizb ut-Tahrir are not interested in discussing the details of the proposed Islamic Caliphate. They believe that nothing to discuss for all is considered to have clearly been explained in the writings of their leaders particularly that of Taqi al-Din al-Nabhani. The more important for them here is a psychological need to believe that great Islamic Caliphate will emerge as inescapable entity to bring back the Muslim glory and as a counterbalance to the Western domination in the contemporary society just like Islamic Caliphate did so in the first centuries of Islam and the medieval age. In this regard, Roy is true when he writes: "The Hizb ut-Tahrir speaks of Caliphate or Khilafah without any historical nor geographical consideration, as if the Caliphate was some sort of dream...". ${ }^{71}$

Hizb ut-Tahrir's ideas and struggles for Islamic Caliphate and global citizenship are also in accordance with Anderson's theory of imagined communities as a form of social constructionism in which he rejects the actual reality of nationalism. ${ }^{72}$ In Anderson's definition of the nation, "it is the imagined political community and imagined as both inherently 236.

${ }^{70}$ Taqiuddin al-Nabhani, The Islamic State, London: Al-Khilafah Publications, 1998,

${ }^{71}$ Oliver Roy, Globalized Islam, New York: Columbia University Press, 2004.

${ }^{72}$ Anderson, Imagined Communities..., 6. 
limited and sovereign". ${ }^{73}$ This also clearly indicates the utopian element in the ideas and struggles for Islamic caliphate and global citizenship.

However, this does not mean that Hizb ut-Tahrir operates outside framework of modernity or against globalization. As some scholars point out, globalization involves the development of post-national citizenship. It is argued that this new development leads to the weakening of national citizenship and at the same time to the rise of universal modes of membership within the deterritorialised notion of global citizenship.This 'secular' post-national citizenship is closely connected to a greater global interdependence, transnational interconnectedness, overlapping membership of various kind of citizenship, and the rise of universalistic rules and international codes and laws such as human rights advocated by international organizations or institutions such as United Nations and European Union. ${ }^{74}$

It is within this context that Hizb ut-Tharir's vision of a global Muslim community should be situated. It is a global force that challenges the traditional notion of citizenship by envisioning a post-national citizenship of Islamic Caliphate. In this sense, Hizb ut-Tahrir envisions and supports what so called a global (not cosmopolitan) citizenship. This is also connected to the rise of global interconnectedness and interdependence among people and universalistic rules and laws. But, what distinguishes Hizb ut-Tahrir from other global forces is that its challenge to the nationstate and its notion of global citizenship are founded and motivated not by secular ideology, but rather by religious ideology. As a result, it is a 'religious' global force based and motivated by universalistic rules and codes derived from a particular way of interpreting Islamic doctrines and history.

${ }^{73}$ Anderson, Imagined Communities..., 6.

${ }^{74}$ John Urry, "Globalization and Citizenship", Journal of World-System Research, Vol. V, No. 2, Summer (1999), 311-324. 


\section{Conclusion}

This essay has shown that, contrary to the most perceived wisdom, Islamic fundamentalism is not anti globalization movement. Rather, Islamic fundamentalist movements constitute as parts, participants, and interpreters of globalization characterised by their challenge to nationstate and vision of establishing a global citizenship of ummah. As Jose Casanova maintains, globalization itself facilitates the return of the old civilizations and world religions. Imagined communities, local, national, and transnational, are engaged in competition with each other. "While new transnational imagined communities will emerge, the most relevant ones are likely to be once again the old civilizations and world religions". ${ }^{75}$

This is well exemplified by Hizb ut-Tahrir, a global Islamic movement, that can be said as one of global players in the current political and cultural arena. Just like other global forces, Hizb ut-Tahrir operates across national borders and challenges the existence of the nation-state. It likely has strong presence all over the world including Europe, America, Asia, and Australia. Its extensive use of global media, particularly the internet, has become another proof of the movement's involvement in the globalization processes. Moreover, Hizb ut-Tahrir's ambition to re-establish the Islamic Caliphate, a global citizenship for all Muslims in the world, can be understood as its ambition to position itself as a global player and to interpret globalization for its needs and interests.

However, the growth of Islamic fundamentalism represents what Turner calls paradoxes of religion and modernity. ${ }^{76}$ It may be true that the rise of Islamic fundamentalism is a negative reaction to moderniza-

${ }^{75}$ Jose Casanova, "Religion, the Millenium, and Globalization" Sociology of Religion 62, 4 (2001), 415-441.

${ }^{76}$ Bryan S. Turner, 'Cosmopolitan Virtue: On Religion in a Global Age,' European Journal of Social Theory 4. 2 (2001), 131-152. 
tion that includes capitalism and secularization, but it is inadequate to label it a traditional reaction. Islamic fundamentalism is "a modernization movement rather than a defence of traditionalism". It can be said as a fundamentalist modernism which attempts "to impose certain conditions of uniformity and coherence on societies in order to reduce the uncertainties that result from the hybridity and complexity of the globalization process”. As Turner says, Islamic fundamentalism is not a traditionalist movement because it believes that the gate of ijtihad (the act of interpretation of the religious texts in the light of contemporary issues) is not closed, as the traditionalists believe. In practice, Islamic fundamentalists are involved in the reinterpretation process in that they attempt to impose their perspectives over current issues and existing customary practices which have compromised with Islamic traditions.

In sum, as well exemplified by Hizb ut-Tahrir, Islamic fundamentalism is a part and force of globalization that challenges the existence of nation-state and aspires for a global citizenship. Regardless its utopian nature, Hizb ut-Tahrir is a globalization phenomenon that constitutes a return of old world religions, which is characterised by its rejection of the validity of nation-states and vision of an imagined global community of believers with universalistic rules within contemporary Muslim societies.

\section{Bibliography}

Anderson, Benedict. The Imagined Communities: Reflections on the Origin and Spread of Nationalism. Revised Edition. London:Verso, 2006.

Albrow, Martin. The Global Age. Stanford: Stanford University Press, 1996. Beyer, Peter. Religion and Globalization. London: Sage publications, 1994. Bunt, Garry. Islam in the Digital Age: EJihad, Online Fatwas and Cyber Islamic Environments. London: Pluto Press, 2003.

Euben, Roxanne L. Enemy in the Mirror: Islamic Fundamentalism and the Limits of Modernity. Princeton: Princeton University Press, 1999. 
Barber, Benjamin. "Democracy and Terror in the Era of Jihad vs. McWorld", in K. Booth and T. Dunne. Worlds in Collision: Terror and the Future of Global Order. Basingstoke: Palgrave, 2002.

Casanova, Jose. "Religion, the Millenium, and Globalization," Sociology of Religion 62, 4 (2001): 415-441.

Crenshaw, Martha. "Why America? The Globalization of Civil War", Current History December (2001): 425-432.

Cronin, Audrey Kurth. "Behind the Curve: Globalization and International Terrorism", International Security, Vol. 27, No.3 Winter (2002-2003): 3058.

Gruen, Medeleine. "Hizb-ut-Tahrir's Activities in the United States", Terrorism Monitor, Vol. V, Issue 16 (2007): 7-9.

Held, David and McGrew, Anthony. "The Great Globalization Debate: An Introduction," in David Held and Anthony McGrew (eds.). The Global Transformation Reader: An Introduction to the Globalization Debate, London: Polity Press, 2000: 1-45.

Hizb ut-Tahrir Britain, "Media Information Pack", www.hizb.org.uk, viewed 10 May 2008.

Horton, J. "Hizb ut-Tahrir: Nihilism or Realism?", Journal of Middle Eastern Geopolitics, Vol. 2, No. 3 (2006): 71-83.

International Crisis Group (ICG). "Radical Islam in Central Asia: Responding to Hizb ut-Tahrir", Asia Report No. 58, 2003.

Jurgensmeyer, Mark. "Thinking Globally about Religion”, Global $\mathcal{E}$ International Studies Program, Santa Barbara: University of California, 2002.

Khatib, Lina. "Communicating Islamic Fundamentalism as a Global Citizenship", Journal of Communication Inquiry, 27, 4 (2003): 389-409.

Karagiannis, Emmanuel and McCauley, Clark. "Hizb ut-Tahrir al-Islami: Evaluating the Threat posed by a Radical Islamic Group that Remains Nonviolent", Terrorism and Political Violence 18 (2006): 315-334.

Lechner, Frank J. "Defining Religion: A Pluralistic Approach for the Global Age”, paper presented for the Society for the Scientific Study of Religion Meeting, Houston, October 2000.

Mandaville, Peter. Transnational Muslims Politics: Reimagining the Umma. London and New York: Routledge, 2001.

Marty, Martin E. and Appleby, R. Scott. Fundamentalism Comprehended. Chicago: Chicago University Press, 1995

Mowlana, Hamid. "The Renewal of the Global Media Debate:Implications for the Relationship between West and the Islamic World", in Kai Hafez 
(ed.), Islam and the West in the Mass Media. Cresskil, NJ: Hampton Press, 2000: 105-118.

Al-Nabhani, Taqiuddin. Concepts of Hisb ut-Tahrir (MafahimHizb ut-Tahrir). London: Khilafah Publications, n.d.

Al-Nabhani, Taqiuddin. The Islamic State. London: Al-Khilafah Publications, 1998.

Pankhurst, Reza. The Inevitable Caliphate: A History of the Struggle for Global Islamic Union, 1924 to the Present. New York: Oxford University Press, 2013.

Raymond, Gregory A. "Westphalia", in M. Griffith (ed.), Encyclopedia of International Relations and Global Politics. London: Routledge, 2005.

Robertson, Roland. Globalization: Social Theory and Global Culture. London: Sage, 1992;

Roy, Oliver. Globalized Islam. New York: Columbia University Press, 2004.

Saikal, Amin. "Islam and the West", in Greg Fry \& Jacinta O'Hagan (eds.), Contending Images of World Politics, London: McMillab Press, 2000: 164177.

Saunders, Robert A. "The Ummah as Nation: A Reappraisal in the Wake of the "Cartoon Affairs", Nations and Nationalism 14, 2 (2008): 303-321.

Taji-Farouki, Suha. "Islamists and the Threat of Jihad: Hizb al-Tahrir and alMuhajiroun on Israel and the Jews", Middle Eastern Studies, Vol. 36, No. 4 (2000): 21-46.

Turner, Bryan S. "Cosmopolitan Virtue: On Religion in Global Age", European Journal of Social Theory 4, 2 (2001): 131-152.

Urry, John. "Globalization and Ccitizenship", Journal of World-System Research, Vol. V, No. 2 Summer (1999): 311-324. 